\title{
EXAMINING THE EFFECTS OF PEER REVIEWING ON STUDENTS' COMPETENCE IN WRITING ARGUMENTATIVE TEXT AT THE FOURTH SEMESTER OF ENGLISH DEPARTMENT OF STAIN WATAMPONE
}

\author{
Musfirah \\ musfirah@gmail.com \\ Program Studi Tadris Bahasa Inggris \\ Institut Agama Islam Negeri (IAIN) Bone
}

\begin{abstract}
The research aimed at finding out (1) The effectiveness of peer reviewing in enhancing the writing competence of the students of STAIN Watampone. (2) The writing components: content, organization, vocabulary, language use, and mechanics in that are mostly affected in the use of peer reviewing technique. This research applied a quasi-experimental method to two groups. The experimental group applied peer reviewing technique while the control group applied self assessment technique. The subjects of this research were the students of the fourth semester English Department of STAIN Watampone. The sample was chosen by applying cluster random sampling technique. In collecting data, the researcher used writing test in pretest and posttest. The data that was used in the form of quantitative data in the form of test results to write argumentative text. Then the results were analyzed by T-Test and ANOVA analysis using SPSS version 20 Program. The results of the analysis of the data showed that (1) peer reviewing techniques can enhance the quality of learning outcomes and process of writing argumentative text. It was proved by the mean score of posttest of experimental group was 75.16 while mean score of post test of control group was 68.85. The mean score of posttest was higher than the mean score of pretest (75.16>68.85). (2) The writing component was most affected of the use of peer reviewing was content (M: 22.05).
\end{abstract}

Keywords: peer review, argumentative paragraph, students' writing competence

\section{INTRODUCTION}

Writing is a process of transforming ideas into words on papers in appropriate and accurate ways. Pollard (2008:49) states that writing is a productive skill and, as such, the 
way we treat it in class has some similarities with the teaching and learning of speaking. Learning to write is uniquely challenging. It requires the mastery and concurrent use of a complex array of language skills, from vocabulary and spelling to the ability to organize and convey ideas. It has always occupied a place in most English subject. One of reasons is that people need to learn to write in English for academic purpose. In the 'writing' there are some important things that must be considered. Writing subject is actually very closely also associated with Grammar (Structure), especially on the pattern of the sentence in the text. The second is the 'vocabulary'. Selection of the vocabulary should be appropriate to the reader. The readers can easily understand the terms, especially technical terms, which are in writing. The third is 'punctuation'. Punctuation is also very important in writing. For punctuation has important functions such as maintaining the continuity between the ideas in paragraphs and facilitate readers to understand the message that is in writing. English students need to learn writing and prepare for the academic assignment, script and others. From this, in term of students' needs, writing is necessary.

The researcher interviewed some students of STAIN Watampone on 28 January 2015 who had studied writing subject in the third semester. The students do not consider writing as leisure and easy activity. The lecturer does not give the students effective activity in learning writing. Lecturers who teach writing still use traditional teaching methods or strategies in which students hear, record and make an example in accordance with the instructions from the lecturer after it is completed. the communication process of learning that occurs at time tends to one-way communication (from lecturer to students), only occasional two-way communication; Writing learning process is currently lacking and even challenge students to think critically, analytically, and create competition, do not motivate them to think independently on a topic in writing, and student' work only checked by the lecturer only and then returned to the value that has been given.

Based on the explanation above, lack of student writing competence is influenced by the teaching technique applied by the lecturer. Technique plays an important role for the success of students in the learning so that the students' writing skills becomes a problem and it needs to be improved. The researcher thinks that is necessary to give a technique, which can solve their problem. The researcher decides to look at further information about teaching writing by using peer reviewing. Peer reviewing will be used to teach writing. Purwanto (2008: 19) states that peer reviewing technique refers to the activity of students in writing and then makes a response (in the form of correction) in his position as a reader. The 
researcher expects that this research can give some contributions for the students, lecturers and the process of teaching and learning writing. It can be used as measurements on students' writing competence through peer reviewing that can be applied in writing class.

Based on the statements above, the researcher was interested in conducting a research under the title "Examining the Effects of Peer Reviewing on Students' Competence in Writing Argumentative Text at the Fourth Semester of English Department of STAIN Watampone".

In line background above, the research question was put forward as in the following, 1. Does the use of peer reviewing affect the writing competence of the students of STAIN Watampone? 2. Which writing component is mostly affected by the use of peer reviewing in terms of content, organization, vocabulary, language use, or mechanics? Deals with the research question, the objective of this research were to find out the affect of using peer reviewing to the writing competence of the students of STAIN Watampone and to find out which writing component is mostly affected by the use of peer reviewing in the terms of content, organization, vocabulary, language use, or mechanics.

\section{LITERATURE REVIEW}

\section{Concepts of Writing}

Byrne (1997: 1) states that we produce a sequence of sentences arranged in a particular order and linked together in certain ways. Meyers (2005:2) states that writing is an action, a process of discovering and organizing ides, putting them on a paper and reshaping and revise them. The present researcher concluded that writing is a process of thinking and organizing the written word to share idea or information with others. Writing is the ability to be active and productive in generating writings acquired through learning and practice constantly. According to Hedge (1988: 20-22) writing process approach is an approach to teach writing that allows students to write their own ideas with their own process. The writing process approach includes five steps: pre writing, drafting, revising, editing and publishing. In addition, Heaton (1988:135) then classified the components of writing into five areas. They are content, organization, vocabulary, language use, and mechanics. 


\section{Concepts of Peer Reviewing}

Seattle (1998:2) states that peer reviewing does not preclude teacher feedback, but is meant to supplement it. Students value both types of feedback. As stated by Brown (1999:7), peer reviewing refers to engaging learners in the process of sharing their ideas and receiving as well as offering constructive comments and suggestions for improving a piece of writing. Peer reviewing- students giving comments on another's work with the intention of helping their friends revise and improve their writing. The present researcher concluded that peer reviewing is the way of interaction between students to identify, correct the peer's mistake, share or exchange information improve their writing with each other or friends what they have written.

\section{The Benefit of Peer Reviewing}

Jahin (2012) emphasizes that the positive impacts of peer reviewing, such as enhancing positive attitudes towards writing within students; giving students a sense of audience; increasing their motivation and confidence in their writing; helping them learn to evaluate their own writing better and fostering collaboration and creating positive environment for learning. By learning to evaluate one another's writing, students can also learn new ideas and vocabulary and internalize criteria of good writing so that they can apply them to future writing situations. Besides, when students know they have more readers for their compositions, they are more motivated to invest efforts in writing. As can be seen from the literature, the researcher concluded the benefit of peer reviewing can be seen as a psychological, socially, and educational. Psychologically, the students can increase motivation to writing and build confidence. Socially, the students can learn how to treat writing as a collaborative social activity, learn how to formulate and communicate constructive feedback on a peer's work and learn how to gather and respond to feedback on their own work. And for educational, peer reviewing can give distribution to the lecturer to use in teaching and learning process, help the lecturer to manage the time in a big class, and give feedback after students correct their work.

\section{Process of Learning through Peer Reviewing}

According to Brown (2001), In the implementation of peer reviewing covers techniques and how to analyze and assess the work of writing through measures such as identifying errors (identifying), describe and classify errors (describing or classifying), discuss alternatives repair (discussing alternative for revising and correcting), recommend 
improvements (recommending for correcting) errors, enrichment and final discussions mediated and facilitated by lecturers to improve and assess the end result of student writing (discussing for final correction and evaluation of students' work). Thus, based on this description, peer reviewing is implemented as follows;

1. Dividing students into peer.

2. The researcher informs the students about peer reviewing. Peer reviewing is the way students exchange their work with the peer, identify the mistakes and discuss or solve the problem. Identify means students know the mistakes writings. In this step the students identify their mistakes in writing. The students are able to classify the mistakes they make is based on the concept of type of error in writing, and students in groups that have been determined to discuss alternatives to the improvement in their knowledge to improve the results of friend's work (peer's work). At this level, students begin to think critically, analytic and synthetic why there is an error and what the likely improvement.

3. The student will identify the components of writing (content, organization, vocabulary, language use, and mechanic)

a. Content

1) All the information relevant to the topic

2) The students know the topic well

3) The paragraph contains a topic sentence

4) The paper has a purpose

b. Organization

1) Clear in expressing the idea, complete, logic and cohesive

2) The students use the correct conjunctions (and, but, so, in addition to, firstly, second, etc.

3) The learner should arrange their writing chronologically. They should present their ideas based on the order of which happened from the beginning to the end.

c. Vocabulary

1) The students are correct in choosing the word

2) The words are appropriate to the topic

3) Choosing the more formal alternative when selecting a verb, noun, or other part of speech 
4) The students make a good meaning

d. Language use

1) The sentence is well formed and complete

2) Generally avoid contractions

3) Use the more appropriate formal negative forms

4) Place adverb within the verb

e. Mechanic

1) The students use capital letter correctly

2) Punctuation is in the right places

3) Almost every word is spelled correctly

4) The students' spelling, punctuation, grammar, and capitalization make the paper easy and understand to read

4. Collaboration, students provide repairs in accordance with the decision of the mistakes that have been found previously. In this phase, the students took the decision to fix the errors according to the understanding, knowledge, and abilities.

\section{Argumentative Paragraph}

Argumentation is used in persuading and convincing. It is closely related to exposition and is often found combined with is. Argumentation is used to make a case or to prove or disprove a statement or proposition. Argumentative paragraph is a paragraph that expresses an idea or opinion of the author accompanied by evidence, and example consider in order to make the reader believes that the ideas or opinions of the author is correct and proven. In general, argumentative paragraph has a structure or organization that is composed of three elements namely the topic sentence (topic sentence), explanatory sentences (supporting details) and a closing sentence (concluding sentence).

\section{METHOD}

\section{Design and Samples}

The researcher applied quasi-experimental design. There were two groups' namely experimental group and control group. The experimental group received treatment (using peer reviewing technique) and the control one received treatment (using self assessment technique). The population of this research was the fourth semester students of English department at STAIN Watampone in the academic year 2015/2016. It consists of Four classes; TBI 1, TBI 2, TBI 3, and TBI 4. The total number of population is 76 students. In 
choosing the sample, the researcher used cluster random sampling. Two of the four classes were selected randomly for experimental and control group. In this way, TBI 3 was as the experimental group and TBI 2 was as the control group. The total sample was 39 students.

\section{Instruments and Procedures}

The instrument of this research was writing test. The researcher used writing test to measure students' ability in writing for both of the experimental and control groups. The test was applied in two sections; the first test (the pre test) was intended to find out the prior knowledge of students' achievement in writing and it was given before treatment. The second test (the post test) was given after the treatment. The test was used as pre test and post test was subjective test, argumentative paragraph. The quality of writing was assessed in terms of the five components of writing; content, organization, vocabulary, language use, and mechanic. Scoring the students achievement, the researcher will use assessment scale for written work by Jacob (1981).

The procedure of data collection was presented chronologically as follows:

1. The sample was divided into two groups: the experimental group and the control group.

2. Pre test

3. The treatment

The researcher gave treatment to the students both the experimental group and the control group. The treatment was conducted for six meetings. The experimental group received the treatment by using peer reviewing technique and the control group received the treatment by using self assessment.

a. Experimental group

The procedures of treatment were implemented as follows:

1) Explaining the definition, generic structure, and example of argumentative paragraph.

2) Introducing the steps learning writing toward peer reviewing

3) Giving the rubrics to identify types of errors

4) Dividing students into peer

5) Giving the topic to students

6) Asking the students make argumentative paragraph related to the topic

7) Asking the students to exchange their writing with their peers after that they comment (identify and correct) the peer's writing 
8) Asking students to revise, reorganize, and edit their work.

b. Control group

The procedures of treatment were implemented as follows:

1) Explaining the definition, generic structure of argumentative paragraph.

2) Giving the topic to the students

3) Asking the students to write argumentative paragraph relates to the topic is given

4) Monitoring the students activities in class

5) The students identify and correct their writing by themselves

4. Post test

\section{Data Analysis}

1. Primary analysis of components of writing

The primary data analysis of components of writing is analytic method. This method consisted of the separate of various feature of a composing for scoring purposes. The research focused on the students' five components of writing, namely content, organization, vocabulary, language use, and mechanics. Below is the classification of the ESL Composition Profile Jacob, et al. 1981.

2. Converting and classifying the score of the students

As the scoring of students' competence on writing was somehow subjective, an interrater scoring procedure was used. Two raters scored the students' writings based on the five categories namely content, organization, vocabulary, language use, and mechanics. Two raters, the researcher as rater 1 and the colleague (Nini Salwa Istiqamah) as rater 2 scored the students' essays based on the categories illustrated in table 3. After that, the score from the researcher and the colleague was added then divided into two. Thus, it was of importance to check the reliability of the assigned scores by the two raters. Inter rater reliability is the degree of agreement among raters. It gave a score of how much homogeneity, or consensus, there was in the ratings given by raters.

After tabulating the students' scores, the researcher classified of the students' score based on the following table of rating scale: 
Table 1. Classifying the Scores

\begin{tabular}{lll}
\hline No & Score & Classification \\
\hline 1 & $86-100$ & Very Good \\
2 & $71-85$ & Good \\
3 & $56-70$ & Average \\
4 & $41-55$ & Poor \\
5 & $<40$ & Very Poor \\
\hline & & (Depdiknas in Hasriani, 2013)
\end{tabular}

Data on the students' writing test was analyzed by using the Statistical Production and Service Solution (SPSS), Statistics 20 through quantitative analysis.

\section{RESULTS AND DISCUSSION}

The findings consist of the data analysis result description regarding to the students' writing in writing argumentative text treated at the experimental group and the control group of the students' STAIN Watampone in learning how to write argumentative text trough Peer Reviewing. Furthermore, the discussion deals with data elaboration and interpretation of the findings.

After conducting a pretest for both experiment and control group, the mean scores and standard deviation of the two groups' pretest scores in the following tables:

Table 2. The Mean Score and Standard Deviation of Students' Pretest Scores at the experimental and control group

\begin{tabular}{ccc}
\hline Group & Mean Score & Standard Deviation \\
\hline Experimental & 48.00 & 7.87 \\
Control & 65.35 & 10.71 \\
\hline
\end{tabular}

Table 2 shows the mean scores and standard deviation of the experimental group and control group before the students are given a treatment. The table above shows that the pretest mean score of the experimental group was $\mathbf{4 8 . 0 0}$ which was categorized as poor category while the pretest mean score of the control group was $\mathbf{6 5 . 3 5}$ which was categorized as average. The data indicate that the mean score of the students' writing competence in pretest was quite different.

Like the pretest scores previously, the researcher also presents the mean scores and standard deviation of the students' posttest scores in the following table in order that the data as to the students' ability in writing argumentative text are more noticeable. 
Table 3. The Mean Score and Standard Deviation of Students' Posttest Scores

\begin{tabular}{ccc}
\hline Group & Mean Score & Standard Deviation \\
\hline Experimental & 75.16 & 11.19 \\
Control & 68.85 & 9.74 \\
Difference (D) & 6.31 & \\
\hline
\end{tabular}

Table 3 shows that the mean score and standard deviation of the experimental group and control group. The posttest mean score of the experimental group was 75.16 which categorized as good while the control group's mean score was 68.85 which categorized as average category. This indicates that the posttest mean score of the experimental group was higher than the posttest mean score of the control group; $75.16>68.85$ and the difference was 6.31 points.

\section{Data Analysis Result Description Obtained through Inferential Statistics}

The hypotheses are tasted by using inferential statistics. In this case the researcher used T-Test (test significance) for independent sample test. A test is to know the significant difference between result if the students' score in pretest and post test in experiment and control group and the result of t-test was calculated by using SPSS version 20 program. After using such statistics, the researcher found the probability value of t-test as seen in the following table 4.

Table 4. The Probability Value of T-Test of Pretest in Experimental and Control group

\begin{tabular}{llll}
\hline Variable & P-Value & Alpha & Remark \\
\hline $\begin{array}{l}\text { Pretest of experiment and } \\
\text { control group }\end{array}$ & 0.00 & 0.05 & Significant \\
\hline
\end{tabular}

Based on the result of data analysis as summarized in table 4, it can be seen that the P-value (0.00) is smaller than alpa (0.05) the level of significant. From this finding, it can be stated that the difference between the students ability in writing argumentative text both experiment and control group was significant.

Furthermore, the researcher also found the gain or difference score of posttest both experimental and control group through SPSS version 20. The result shows in the following table; 
Table 5. The Probability Value T-test of Posttest in Experimental and Control Group

\begin{tabular}{llll}
\hline Variable & P-Value & Alpha & Remark \\
\hline $\begin{array}{l}\text { Posttest of experiment and } \\
\text { control group }\end{array}$ & 0.03 & 0.05 & Significant \\
\hline
\end{tabular}

The table 5 above shows that the probability value is lower than alpa (0.005) $0.03<0.05$. It indicated that the difference between the students' ability of posttest in experiment and control group is significant.

Table 6. Hypothesis Test Summary

\begin{tabular}{llllllll}
\hline \multicolumn{7}{c}{ Tests of Normality } \\
& \multirow{2}{*}{ GROUP } & \multicolumn{7}{c}{ Kolmogorov-Smirnov ${ }^{\mathrm{a}}$} & \multicolumn{3}{c}{ Shapiro-Wilk } & \\
\cline { 3 - 8 } & & Statistic & $\mathrm{df}$ & Sig. & Statistic & Df & Sig. \\
\hline \multirow{2}{*}{ Posttest } & Experimental & .203 & 19 & .038 & .911 & 19 & .076 \\
& Control & .146 & 20 & $.200^{*}$ & .953 & 20 & .414 \\
\hline
\end{tabular}

After examining the data through normality test to determine whether the data have to be tested through parametric, the researcher found that the data both in pretest and posttest were normally distributed since the significance values of the posttest groups were higher than the significance level $(\alpha)$; it is $0.076>0.05$. After having calculation through SPSS 20.0 version program, the researcher found that the null hypothesis was rejected with significance value (0.076) that was higher than the significance level $(\alpha ; 0.05) ; 0.076>0.05$.

\section{Test of Analysis of Variance (ANOVA)}

Table 7. Test of analysis of variance

\begin{tabular}{|c|c|c|c|c|c|}
\hline \multicolumn{6}{|c|}{ ANOVA } \\
\hline & & & & & \\
\hline & $\begin{array}{l}\text { Sum of } \\
\text { Squares }\end{array}$ & df & Mean Square & $\mathrm{F}$ & Sig. \\
\hline Between Groups & 3579,642 & 4 & 894,911 & 122,915 &, 000 \\
\hline Within Groups & 655,263 & 90 & 7,281 & & \\
\hline Total & 4234,905 & 94 & & & \\
\hline
\end{tabular}

For doing test of variance, if the significant score (probability) $>0.05$ (was bigger than 0.05 ) so the data had same variance. If the significant score (probability) $<0.05$ (was smaller than 0.05 ) so the data had different variants.

From the data above, it could be seen that the score of probability significant 0.000 so the data above had different variants in which $(0.00<0.05)$. 
Table 8. The Descriptive of Writing Component

\begin{tabular}{|c|c|c|c|c|c|c|c|c|}
\hline \multicolumn{9}{|c|}{ Descriptives } \\
\hline \multicolumn{9}{|c|}{ Posttest } \\
\hline & \multirow[t]{4}{*}{$\mathrm{N}$} & \multirow[t]{4}{*}{ Mean } & \multirow{4}{*}{$\begin{array}{l}\text { Std. } \\
\text { Deviation }\end{array}$} & \multirow{4}{*}{$\begin{array}{l}\text { Std. } \\
\text { Error }\end{array}$} & $95 \%$ & Confidence & \multirow[t]{4}{*}{ Min } & \multirow[t]{4}{*}{$\operatorname{Max}$} \\
\hline & & & & & \multicolumn{2}{|c|}{ Interval for Mean } & & \\
\hline & & & & & Lower & Upper & & \\
\hline & & & & & Bound & Bound & & \\
\hline Content & 19 & 22.0526 & 4.12948 & .94737 & 20.0623 & 24.0430 & 14.00 & 27.00 \\
\hline Organization & 19 & 15.8947 & 2.23345 & .51239 & 14.8182 & 16.9712 & 12.00 & 20.00 \\
\hline Vocabulary & 19 & 16.0526 & 2.14667 & .49248 & 15.0180 & 17.0873 & 13.00 & 20.00 \\
\hline Language Use & 19 & 18.3684 & 3.02233 & 69337 & 16.9117 & 19.8251 & 12.00 & 22.00 \\
\hline Mechanics & 19 & 3.7895 & .78733 & .18063 & 3.4100 & 4.1690 & 2.00 & 5.00 \\
\hline Total & 95 & 15.2316 & 6.71209 & .68865 & 13.8643 & 16.5989 & 2.00 & 27.00 \\
\hline
\end{tabular}

The description of table above, it is presented information about the data in which column shows the sum of each data to writing component of experimental group. Mean column presents mean score for each components of writing. From the result above, component in writing dominantly enhance is content. The students can develop their idea and relevant to the topic. Then, component also has higher score is language use. The students can form and complete the sentence well, the students can use the agreement, tense and word well. The component has higher score after language use is vocabulary. The students can use the correct words, and the meaning is not obscured. Then, the component has higher score after vocabulary was organization, the students could organize the logical idea, support idea clearly, make cohesive sentence or paragraph. And the last, the component has higher score after organization is mechanics, the students can use the appropriate punctuation, capitalization, and the word spelling correctly.

So, it indicates that the students' scores in improving students' writing competence have different variance. It was proved from the multiple comparisons table by which the five aspects namely content, organization, language use, and mechanics have varied mean difference.

By comparing the frequency, percentage, mean score, standard deviation of the experimental group and control group, it was found that the students' ability of the experimental and control group in writing argumentative text before conducting the treatment was different in which the ability of experimental group was at poor level and the ability of control group was average. However, after conducting the treatment, the researcher found a significant difference in the students' ability to write argumentative text 
between the experimental group treated through peer reviewing and the control group treated through self assessment. In this case, the students' ability of the experimental group treated peer reviewing was at good level after learning. On the other hand, the students' ability of the control group to write argumentative text was at average level. Certainly, it can be concluded that the use of peer reviewing was more effective in improving the students' writing ability than of conventional way from the lecture (self assessment).

The students' ability to write an argumentative text improved after implementing peer reviewing. The students had significant progress and made positive changes. In experimental group had been given a treatment through peer reviewing, the students had balance use of their English writing skill, they also had confidence in their writing; helping them learn to evaluate their own writing better and fostering collaboration and building their critical analysis and strength positive feedback. By learning to evaluate one another's writing, students can also learn and develop new ideas and vocabulary. These facts were in lined with the research result found by Jahin (2012). He emphasized that the positive impact of peer reviewing such as enhancing positive attitudes towards writing within students; giving students a sense of audience; confidence in their writing; helping them learn to evaluate their own writing better and fostering collaboration and creating positive environment for learning. By learning to evaluate one another's writing, students can also learn new ideas and vocabulary and internalize criteria of good writing.

Certainly, the statistical result above told us that the students' writing competence of the fourth semester of English Department of STAIN Watampone significantly improved or was affected by the use of peer reviewing. All of the students participated actively during the process of teaching and learning. Hence, most of the students could develop their ideas about what they were going to write and they could organize their ideas into a paragraph.

The result above is in line with the research result found by Jahin (2012) who carried out a research entitle "The Effect of Peer Reviewing on Writing Apprehension and Essay Writing Ability of Prospective EFL Teachers" Jahin claimed that peer reviewing gave positive impacts on students' writing apprehension and essay writing ability. 


\section{CONCLUSIONS AND SUGGESTIONS}

Based on the findings and discussion in the previous chapter, the researcher gives conclusions of the findings in enhancing the students' writing competence as follows:

1. The fourth semester students' writing competence of English Department of STAIN Watampone significantly improved to write argumentative text. The students of the fourth semester of English Department of STAIN Watampone have better writing ability after being treated through peer reviewing. It was proved by the mean score of posttest of experimental group was higher than the mean score of posttest of control group (75.16>68.85). This finding indicates that peer reviewing was effective in enhancing the students' writing competence, especially in writing argumentative text.

2. The researcher result derived also that from the five components in writing namely content, organization, vocabulary, language use, and mechanics. There was a significant difference of the students' ability to write an argumentative text. The content aspect was enhancing the highest of all because content in writing means how well a student to write an idea clearly so the reader can understand the message conveyed. While mechanics was lowest score the students could get because mechanics is all about capitalization, punctuation, and spelling which need lot of practice and application. It means that the students somehow need more time to practice their mechanics ability.

In relation to the conclusion above, the researcher puts forwards some suggestions as follows:

1. In teaching English, the lecturers specially who teach writing are suggested to apply peer reviewing as an effective technique in enhancing the students' writing competence.

2. The lecturer should be able to implement a peer reviewing techniques for teaching writing learning materials. In addition, teachers should provide more opportunities for students to practice writing in order to increase the quality of students' writing.

3. For the other researcher is expected to be able to conduct a research on other strategies in different, new and innovative teaching technique and involve the students in teaching and learning process, in order to the aptitude, potential, and creativity of the students can thrive. 


\section{REFERENCES}

Brown, S. 1999. Institutional Strategies for Assessment. In Brown. S. and Glasner. A. (Ed.) (1999). Assessment Matters in Higher Education. Choosing and Using Diverse Approaches. Buckingham. Open University Press. pp. 3-13.

Byrne, Donn. 1997. Teaching Writing Skills. New York: Longman, Inc.

Boardman, C. A. 2002. Writing to Communicate (Paragraph and Essay).New York: Longman.

Heaton, J.B. 1988. Writing English Language Test. London and New York: Longman.

Hedge, Tricia. 1988. Writing: Resource Books for Teachers. Oxford University Press.

$\mathrm{Hu}, \mathrm{G}$. and Tsui E. L. S. (2010). Issues of cultural appropriateness and pedagogical efficacy: exploring peer review in a second language writing class. Instructional Science, 38(4):371-394.

Jahin, Jamal H. 2012. The Effect of Peer Reviewing on Writing Apprehension and Essay Writing Ability of Prospective EFL Teachers. Australian Journal of Teacher Education. Volume 37 | Issue 11.

Meyers, Allan. 2005. Gateways to Academic Writing: Effective Sentences Paragraph and Essay. New York: Longman.

Pollard, Lucy. 2008. Lucy Pollard's Guide to Teaching English.

Purwanto, J. 2008. Upaya Meningkatkan Kemampuan Menulis Ilmiah melalui Teknik Peercorrection pada Siswa Kelas XI IA SMA Muhammadiyah 3 Masaran. Universitas Sebelas Maret, Surakarta.

Seattle. 1998. Peer Review Methods for ESL Writing Improvement. Colleen Soares . Hawaii Pacific University.

Walz, Joel C. 1982. Correction Techniques for the Foreign Language Classroom. Language in Education: Theory and Practice Series No. 50. Washington D.C.: Center for Applied Linguistics. 